\title{
Amplifying and nullifying the impact of democratic sanctions through aid to civil society
}

\section{Paulina Pospieszna \& Patrick M. Weber}

To cite this article: Paulina Pospieszna \& Patrick M. Weber (2020): Amplifying and nullifying the impact of democratic sanctions through aid to civil society, International Interactions, DOI: 10.1080/03050629.2020.1791108

To link to this article: https://doi.org/10.1080/03050629.2020.1791108

曲 Published online: 26 Jul 2020.

Submit your article to this journal $\pi$

山 Article views: 147

Q View related articles ๘

View Crossmark data \lceil 


\title{
Amplifying and nullifying the impact of democratic sanctions through aid to civil society
}

\author{
Paulina Pospieszna a and Patrick M. Weber \\ ${ }^{a}$ Adam Mickiewicz University in Poznan; bUniversity of Konstanz
}

\begin{abstract}
Both foreign aid and sanctions are foreign policy tools to promote democracy. Yet, it is unclear how far incentives and coercion enhance democratization. Since sanctions and aid are often employed at the same time, the goal of this study is to determine their joint effect on democratization in target/recipient countries. We argue that sending democracy aid through civil society organizations enhances the effectiveness of sanctions as a democracy promotion tool because the civil society is empowered to introduce democratic changes. Thus, in addition to the top-down pressure on the target government created by sanctions, there is a bottom-up pressure exerted by the civil society. Our empirical results show that democratic sanctions by the European Union and the United States are more likely to have a positive effect when aid flows bypass the government. Conversely, aid channeled through the public sector mitigates the generally positive effect of sanctions on democracy. In order to estimate these joint effects, we employ a new comprehensive dataset on economic sanctions: the EUSANCT Dataset which integrates and updates existing databases on sanctions for the period between 1989 and 2015, merged with disaggregated OECD aid data and V-Dem democracy scores.
\end{abstract}

\section{KEYWORDS}

Sanctions; democracy aid

civil society aid; aid

effectiveness;

democratization

\section{Introduction}

There are different means and instruments of democracy promotion, which are available to states and international organizations to incentivize other states to further democratization or to protect and respect human rights. In our article, we do not consider the impact of such foreign policy tools separately, but instead we study the impact of sanctions and foreign aid on democratization interactively. More specifically, we address the following research questions: What is the joint effect of sanctions and aid on the democratic performance of target states? And what is the impact of aid on the effectiveness of democratic sanctions?

Few studies have explored in a systematic way how sanctions and foreign aid interact with each other when they are both used to induce changes in target/recipient countries. Scholars find that sanctioning efforts against targets

CONTACT Paulina Pospieszna paulina.pospieszna@amu.edu.pl Faculty of Political Science and Journalism, Adam Mickiewicz University in Poznan, Poznan 61-614, Poland

(- Supplemental data for this article can be accessed on the publisher's website. 
that receive massive financial support are less likely to be effective (Early and Jadoon 2016; Lektzian and Souva 2007). We believe that this finding is driven by the fact that aid is mainly given to the public sector. Sanctions lose their credibility if they are accompanied by aid to the target government and senders might be less eager to enforce sanctions if they have previously sent a relatively high amount of aid (sunk-cost fallacy). Moreover, target governments may use these previous payments to diminish the impact of sanctions. High levels of development aid to the government thus mitigate the positive effects of restrictive measures. We might even expect this combination to have a negative effect on the level of democracy since the past payments might have already strengthened the government, which eventually becomes immune to sanctions.

Building on the vast literature on aid, sanctions, and democracy, we expect that the effects of sanctions can be amplified via civil society aid and undermined via aid to target governments. Once civil society and opposition groups receive support, they become empowered and exert additional pressure on the sanctioned government. Contrarily, when sanctions are combined with aid channeled to the public sector, this combination nullifies the impact of sanctions as a coercive foreign policy tool. We specifically focus on democratic sanctions that are imposed on the grounds of violating democratic norms and practices by the government in the target country. So we regard democratic sanctions as economic coercion that pursues goals related to democratization. Thus, aid channeled to civil society and democratic sanctions are more likely to have the same goal, whereas general aid and sanctions that are not related to democracy promotion do not have this common objective and can even have contradicting goals.

We think that studying the impact of aid and democratic sanctions especially how aid affects sanctions as a foreign policy instrument - is important as few studies have explored how these tools interact with each other to influence democratization. Case studies provide some inspiration for studying the impact of both instruments in a systematic way. For example, in the 1960s, sanctions were imposed against the governing elites in South Africa to harm their economic interests and to persuade them to take part in negotiations with their political opponents. In addition to this coercive strategy, the international community aimed at empowering and supporting the South African opposition and civil society. The effect of both sanctions and civil society engagement led to the end of apartheid in the 1990s.

This article thus yields new insights into the effectiveness of two forms of democracy promotion. First, we provide a novel contribution to the literature studying the impact of sanctions and aid. Second, the results are important from a practical perspective and can send an important message to policymakers.

To answer our research questions, we derive a theoretical framework and test our hypotheses empirically by analyzing different types of aid flows as well 
as democratic sanctions by the EU and the US, which are the two most important senders of sanctions. The US has always most frequently employed sanctions as a foreign policy tool and since the early 1990s, the EU has become the second most frequent sender of sanctions. These two Western powers are also popular aid donors (Carothers 1999; Youngs 2010). The question is under which circumstances a combination of these two different tools can enhance democratization in target states.

Using a new database on economic sanctions merged with disaggregated aid data and V-Dem democracy scores, we find in our empirical analysis that when aid channeled through NGOs and the civil society is combined with democratic sanctions, there is a significantly positive effect on the level of democratization. The mechanism, which makes the combination of both civil society aid and sanctions successful, works through the simultaneous pressure from outside on the government and the empowerment of civil society, exerting pressure from within the country. In contrast, we find that the combination of sanctions and aid channeled through the public sector has a negative effect on democracy scores since public sector aid strengthens the sanctioned government and mitigates the generally positive effect of sanctions.

\section{The Impact of Sanctions on Democratization}

The aim of sanctions is to signal, often through economic pressure, that the behavior of the regime is unacceptable and should thus be punished. Sanctions raise the costs for the disputed behavior and provide an incentive for the target to change its policy. The focus of this article is, however, not on the success of sanctions understood as concession or compliance with the demands of the sanctions. We consider the impact of sanctions as a coercive tool in the form of democratization in the sanctioned country. By the success of democratic sanctions, we thus mean liberalization or democratization of the recipient state. Scholars point out that democratization can be either a direct outcome of sanctions or a side-effect of sanctions achieved through economic pain.

Several scholars find that sanctioned states experience greater democratization (Hufbauer et al. 2009; Marinov and Nili 2015). Von Soest and Wahman (2015a), focusing on sanctions that explicitly aim to promote democracy, find that although sanctions do not generally increase the level of democracy, there is in fact a significant correlation between measures that aim at democratization and increased levels of democracy in targeted authoritarian countries. Moreover, sanctions can also prevent the backsliding or the breakdown of democracy. Especially today sanctions against democratic states might not be rare cases anymore, as demonstrated by the EU's efforts to pressurize the governments of two member states, Poland and Hungary, to repeal illiberal practices by inter alia imposing material sanctions, namely Article 7 of the Treaty on European Union (Sedelmeier 2014). 
The impact of democratization as a result of the sanctions can also be indirect through destabilization effects on elites. Marinov (2005) finds that economic sanctions lead to political instability in sanctioned countries by destabilizing the target leadership. Although destabilization does not mean that the leaders will decide to liberalize or democratize, it can be a possible mechanism leading to democratization. Moreover, other scholars find that economic sanctions can lead to protests and riots against the established regimes and thus induce a possible regime change (Allen 2008). Dursen and Cooper Drury (2009), Peksen and Cooper Drury (2010) are skeptical about these positive side-effects of economic sanctions as the authors find that there is a negative impact of economic coercion on political liberties. Specifically, this tool unintentionally creates conditions that permit the leadership in target countries to consolidate power and increase the use of political repression. Carneiro and Apolinário (2016), studying the impact of targeted sanctions versus comprehensive ones, also find unintended adverse effects on human rights (rights to life and the prohibition of torture) since a targeted leader can choose to repress protesters and domestic opposition groups.

Although sanctions can cause leaders to become more repressive, which we do not reject, they can also create incentives for opposition groups and civil society and can be helpful in the promotion of democracy. Grauvogel, Licht, and vonSoest (2017) find that sanction threats work as a clear and coherent signal of international approval for protesters and they encourage collective action against governments. The authors provide the example of Zimbabwe, when sanction threats against President Mugabe increased the opportunity for voicing dissent and drove a wave of protests even in the face of likely repression. In our study, we do not focus on threats of sanctions but on imposed sanctions, the impact of which can be greater democratization if the opposition and civil society are additionally encouraged. This encouragement can come from foreign aid channeled to this sector. Although we do not focus on protest activity as an outcome of sanctions, we acknowledge that one of the driving mechanisms of democratic change can be social unrest.

We believe that previous studies overlook the possibility of other external factors that may have a simultaneous impact. Dursen and Drury (2009) acknowledge that "future research could also offer a comparative assessment of whether engagement strategies, that is, foreign aid and provisional economic loans, work more often and cause less damage to civilians than economic coercion." Furthermore, the conclusion of the broader literature on improving governance from "outside-in" is that democratic sanctions sometimes work, though not necessarily on their own (Krasner and Weinstein 2014; Marinov and Nili 2015).

The protection of civil and human rights and the likelihood of democratization can worsen under an episode of targeted sanctions when compared to a situation where there are no sanctions. However, we argue that it is also 
important to consider the simultaneous impact of other tools, which can strengthen or nullify the negative or positive impact of sanctions. Some studies already find that restrictions on IMF loans can be used by sender countries as punishment for target countries to amplify the impact of sanctions regimes (Peksen and Woo 2018). Nevertheless, there are no studies investigating the interesting and important question about the effectiveness of the interaction of sanctions with other democracy promotion tools. Thus, we consider the simultaneous impact of foreign aid, but specifically aid channeled to civil society.

Scholars find that targeted, or so-called smart, sanctions are meant to be less harmful to civilians and more discriminating against specific governing elites as well as a more flexible instrument in ongoing negotiations with the target countries. In our study, we chose not to differentiate between comprehensive versus target sanctions, because sanctions by senders such as the EU and the US are in most instances targeted (i.e. targeted financial sanctions, economic sanctions targeting specific sectors of economy, travel bans, arms embargoes, and so forth). We also argue that the negative view of sanctions as being more harmful or helpful in the promotion of democratic freedoms and human rights depends generally on engagement policies. In other words, foreign aid may create incentives for funded opposition groups and civil society to take action in order to pressure the government in the sanctioned country.

\section{Democratic Aid and Democratization}

Scholars have not been able to establish a clear link between aid flows and the democratization of recipients (Crawford 2001; Dunning 2004; Goldsmith 2001). This is due to the fact that foreign aid is not random, can serve various purposes, such as facilitating economic relations or obtaining concessions from recipient states, and its impact also depends on domestic institutions and political processes in the target country. Scholars find that aid can even contribute to the survival of autocratic leaders and their winning coalitions because of a lack of institutional checks, which can lead to the expropriation of developmental aid and boost a leader's power (Licht 2010, 59). Overall, empirical research shows that aid operates to the benefit of local elites rather than their populations or donors (Boone 1995; Kosack and Tobin 2006; Licht 2010, 65).

Moreover, aid to autocratic regimes can trigger inefficiency, rent-seeking activities, corruption, exclusion of others from engaging in the decisionmaking process and thus undermining good governance in the public sector, hence, decreasing the likelihood for political institutions to become democratic (Abed and Gupta 2002). In light of these negative findings of aid on authoritarian recipient countries, Kalyvitis and Vlachaki (2012) argue that effectiveness of aid can be increased if the private sector is engaged in carrying 
out aid programs, for example voluntary organizations, consulting firms, and similar non-governmental organizations.

In addition to favorable environments for democracy and the engagement of private actors, the effects of aid on democratization depend also on the type of aid. Foreign aid encompasses different activities, ranging from support for education and health, infrastructure, and environmental improvement to democracy-related projects and peacebuilding activities. Some scholars study the indirect effect of foreign aid to promote democratization through economic development (Bermeo 2011; Dunning 2004; Goldsmith 2001) because this traditional development aid may indirectly improve the democratic performance of the recipient country in the long term. In general, studies on foreign aid and democratic change find that aid has little, or even detrimental, effect on democracy in recipient countries (Bräutigam and Knack 2004; Bueno de Mesquita and Smith 2009; Djankov, Montalvo, and Reynal-Querol 2008; Licht 2010; Rajan and Subramanian 2007).

In order to extract the impact of aid on the democratization of recipients, scholars chose to explore the impact of democracy assistance, i.e. "aid specifically designed to foster opening in a non-democratic country or to further a democratic transition in a country that has experienced a democratic opening" (Carothers 1999). Finkel, Pérez-Liñán, and Seligson (2007), focusing on democracy aid provided by the United States Agency for International Development (USAID), find that this type of aid promotes the democratization of recipients. This disaggregated analysis of the democratic effect of aid gave impetus to other empirical investigations of the impact of democracy aid on regime change. Kalyvitis and Vlachaki (2012), for example, find strong evidence that democratic aid, in form of democracy-related programs directed toward the government and civil society, positively affects democratization of recipient countries.

Other scholars provide more refined research by focusing further on the channels of aid delivery (Lührmann et al. 2016). More specifically, Dietrich (2013) argues that it is important to consider that aid delivered to the civil society is likely to have a considerably different impact than aid that goes to governments. The goal of the first is to strengthen the role of non-state actors who will contribute to bottom-up changes in the country. Aid donors may choose to bypass uncooperative or corrupt governments in recipient authoritarian countries and, thus, instead of giving government-to-government aid, they channel aid through non-state actors.

Following these findings, in our research, we focus on the channel of aid delivery because it matters who is in fact owing the aid and who is carrying out aid programs. We believe that the role of the civil society sector has been very important in carrying out aid programs and in having an impact on democratization. A contribution of civil society to democracy depends on the degree to which civil society organizations are able to influence the government and to hold office holders to account (Kalyvitis and Vlachaki 2009); thus aid may 
empower humans and make them capable and willing to place effective pressures on the elites, regardless of the political system. According to Welzel and Inglehart (2008) "human empowerment" is the most important driving force behind effective democratization.

Supporting civil society can be both a promising response to the spread of closing civic spaces (Carothers and Brechenmacher 2014) and a tool to encourage vulnerable civil societies to fight against powerful and misguided governments. We are aware of the fact that in some autocratic states civil society does not receive a steady flow of aid from abroad. Although authoritarian regimes are pushing back against the advances of democracy, there are still ways to support civil society, and aid databases, which differentiate aid flows by the channel of delivery, show that there are indeed aid flows that go to civil society in sanctioned authoritarian countries. The databases report these flows and practice also shows that donors find ways to fund civil society even in countries that close the civic space. We do not condition the ability of civil society to benefit from this assistance and to influence the government on regime type and political processes. Data for civil society aid collected for this study show that 140 countries that are coded as non-democratic according to the Authoritarian Regime Dataset by Hadenius and Teorell receive positive amounts of civil society aid. Thus, there are ways to get around restrictions on foreign aid imposed by autocratic regimes. Moreover, the EU often explicitly targets aid to civil society when sanctions are in place.

\section{Combining Bottom-up and Top-down Foreign Policy Tools to Promote Democracy}

It is well-established in the literature that international factors in the form of positive and negative incentives have a potential to influence democratization in a target country (Whitehead 1996). However, it is up to the targeted states, and specifically the governing elites or a leader, to decide whether to open or close politics (Baldwin 1971, 1980, 1985). When thinking of how a foreign policy tool can be interpreted by a target country's decision-makers, we adopt the argument that the leaders want first and foremost to stay in power (Bueno de Mesquita et al. 2003). However, there can be various mechanisms through which the leaders may revise their policies. Sanctions are coercive measures, which might cause the rational and survival-driven leaders to engage in a costbenefit calculus and choose to democratize. When focusing on the impact of sanctions on liberalization or democratization of the target country, we employ the mechanism mentioned by Marinov (2005) on destabilization of the incumbent. Marinov (2005) finds that pressure in the form of sanctions may destabilize governmental leaders in that this foreign policy tool targets and eventually makes them significantly more likely to lose power the following year. The results hold after adjusting for other determinants of 
leadership survival, such as domestic political institutions, or the level of economic growth, and such.

We incorporate in this logical framework a layer of additional external influences that might amplify or nullify the impact of sanctions on democratization through destabilizing the leaders. External intervention in form of aid may change the balance of power in the domestic arena. Specifically, we argue that aid allocated to civil society may have a positive impact on democratization through producing bottom-up pressure on the leaders, which affects their time in power (Kono and Montinola 2009) as well as the choices of the leading elites to revise disputed policies. This may strengthen the impact of sanctions on democratization. We expect to find, however, a negative impact of aid that is channeled through the public sector. Foreign aid that goes to the public sector will decrease the risks taken by autocratic leaders (Licht 2010, 67) and nullifies the impact of sanctions, thus sending a contradictory message to the targeted country.

Sanctions have an impact on destabilizing the leaders (Marinov and Nili 2005) and provide the opportunity for a foreign-funded civil society to act against the elites, who are weakened by the sanctions. Sanctions may give incentives to civil society actors, who oppose and condemn the actions of the governing elites, to pressure the government to stop human rights abuses or other activities undermining democracy. Thus, aid to civil society from international actors, which was provided long before or after the imposition of sanctions, strengthens their impact once they are implemented. Once sanctions are imposed, foreign-funded civil society already empowered and connected transnationally (Keck and Sikkink 1998), will interpret the sanctions against the regime as a sign to mobilize and to act against the authorities, both in authoritarian and democratizing countries.

In other words, a combination of external and bottom-up pressure may further democratization because coercion in the form of sanctions may directly harm the government and its winning coalition, as well as emboldening opposition activists to protest against the regime (Stephan and Chenoweth 2008). Chenoweth and Stephan (2011) mention that the international sanctions against the apartheid in South Africa were critical in creating bargaining space for the resistance campaigns to come to the negotiating table. This and other examples suggest that sanctions imposed on adversary governments strengthen the opposition's voice and credibility as an important domestic actor.

If civil society was already funded before the imposition of sanctions, it is even more empowered and invigorated to provide bottom-up resistance. Sanctions may also be a signal for the empowered civil society to protest and rebel against targeted (and weakened) elites or pressurize them differently. Aid to civil society additionally empowers it and may change the barraging power and the costs and benefit calculus. 
However, aid channeled to the public sector should have adverse effects and nullify the impact of sanctions. Scholars find that aid recipients tend to receive more foreign aid when they have been sanctioned (Early and Jadoon 2016; Lektzian and Souva 2007). Donors could be motivated to support sanctioned states in order to protect their own commercial interests, even though this might undermine the impact of sanctions. In such situations, although targeted sanctions might harm the governing elites and make them reconsider the behavior, the accumulation of aid that was channeled to the public sector benefits leaders (Kono and Montinola 2009) and can weaken any likely positive outcomes of sanctions on democratization. Aid channeled to the public sector in situations where sanctions are imposed does not help the government to liberalize or to change policies, but somewhat decreases the risks faced by autocratic leaders and helps the regime to continue or even cement their place in power (Licht 2010, 59-67).

Based on the positive and negative interaction effects between aid and sanctions, we thus propose the two following testable hypotheses:

Hypothesis 1: Democratic sanctions are more likely to lead to a higher level of democracy if they are combined with aid for civil society in the sanctioned country.

Hypothesis 2: Democratic sanctions are less likely to lead to a higher level of democracy if they are combined with aid for the public sector in the sanctioned country.

\section{Research Design}

In the empirical part of this article, we aim to test our hypotheses on the effect of democratic sanctions and aid flows on the level of democratization. Therefore, we look at 199 countries between 1989 and 2015, resulting in 5,077 countryyears. These numbers stem from 193 members of the United Nations (some are not included for the whole period of investigation because they joined the United Nations Organization after 1989) as well as Taiwan for the entire period and former UN members during their membership. The unit of analysis is thus the country-year. We run fixed-effects panel models with annual changes in the V-Dem democracy score as the dependent variable and a lagged democracyrelated sanction dummy as well as lagged and logged aid flows per capita as explanatory variables to investigate the impact of sanctions and aid on democratization. The standard errors are clustered at the country-level. Moreover, we include interactions between sanctions and the two different aid flows to see how these flows affect the effectiveness of sanctions. Since the disaggregated aid data is only available from 2004 onwards and sometimes missing, the number of 
country-years drops for our analysis down to 1,326 observations in 129 potential sanction targets and/or aid-receiving countries.

Our key dependent variable measures yearly changes in the V-Dem Electoral Democracy Score (Coppedge et al. 2017; Teorell et al. 2016), which consists of five component indices: an elected executive, clean elections, freedom of organization, inclusive citizenship, and freedom of expression. These components capture Dahl's (1971) institutional guarantees for democratic governance, dubbed "polyarchy," as the latent concept. The V-Dem score is based on responses from over 2,600 country experts to more than "350 detailed questions with well-defined response categories or measurement scales. [...] The target is that at least 5 experts rate each indicator for each country and year" (Teorell et al. 2016, 9). The V-Dem polyarchy measure strongly correlates with the democracy indices provided by Polity and Freedom House, but comes as a continuous variable that ranges from 0 and 1 in comparison to the ordinal FH and Polity scores. Since we are interested in annual changes, the V-Dem data are the superior choice because this continuous variable varies, at least marginally, in more than $75 \%$ of all country-years that we consider. ${ }^{1}$

Our first key independent variable is a dummy that indicates whether there was an ongoing democracy-related sanction case by the EU and/or the US in the previous dyad. ${ }^{2}$ We test the effect of sanctions by using the newly created EUSANCT Dataset (Weber and Schneider 2020), which integrates and updates some of the most widely used sanction data: the Threat and Imposition of Economic Sanctions (TIES) dataset (Morgan, Bapat, and Kobayashi 2014), the HSE dataset (Hufbauer et al. 2009), and the GIGA Sanctions Dataset (Portela and von Soest 2012). The EUSANCT Dataset covers all economic sanctions and sanction threats by the European Union, the United States, and the United Nations from 1989 to 2015 (in sum, 326 observations of which 209 are imposed sanction cases). ${ }^{3}$ The main difference from other datasets is that EUSANCT

\footnotetext{
${ }^{1}$ In contrast, yearly changes in the Polity score within a country are extremely rare. Out of 5,077 country-years, the score does not change in 3,695 instances. Moreover, more than $95 \%$ of all country-years do either not change at all or in a range from -2 to +2 on a scale from -10 to 10 .

${ }^{2}$ As discussed in theoretical part, we believe that sanction threats alone can already have an effect. However, since we do not focus on concessions (as implied by a "successful" threat), but on more long-term and implicit effects of sanctions in the form of changes in the V-Dem score over time, we focus on imposed sanctions here. While a threat is most often either followed by a sanction or dropped after a certain time, sanctions can be ongoing for many years and thus produce other effects on democratization, which can be enhanced by the empowerment of civil society. Moreover, we would not expect to find statistical results for the effect of threats on changes in democracy scores. The reason is that threats are too rare an event to be associated with changes in relatively constant democracy scores. Sanctions are already a rare event: out of 5,077 country-years, there are democratic sanctions imposed by the EU and/or the US in 574 country-years (11\%). However, threats only occur in 111 country-years (2\%). A threat event is thus even rarer than a sanction event such that it is hard to find statistical results.

${ }^{3}$ Since the period before 2005 is comprehensively covered by all existing sanction datasets, EUSANCT used these existing datasets for the identification of relevant cases, but relied on an independent coding of all included variables. By researching each individual case, EUSANCT tried to minimize the dangers of inconsistently coding and duplicating cases that are reported in several datasets. To identify more recent threat and sanction cases, EUSANCT conducted a systematic keyword search using the Nexis news database and other online resources. For the coding of identified cases, the TIES codebook by Morgan et al. (2009, Morgan, Bapat, and Kobayashi 2014) served as the baseline, but EUSANCT introduced new categories and altered some of the extant variable descriptions.
} 
codes, inter alia, information on sanction threats and imposed sanctions for each individual sender, including start and end dates, the identities of those who threatened and imposed sanctions, the (threatened) sanction types as well as the outcome of the respective case. The focus on senders is a distinct feature of EUSANCT, in comparison to more target-focused datasets such as TIES or HSE. In addition, EUSANCT also includes and adopts variables used in other datasets, most notably the HSE effectiveness measure.

Sanctions can involve issues that directly affect the international community, such as exercising political influence over a third state, militarized actions, territorial disputes, alignment choices, weapons production and proliferation, support of terrorist groups, and drug trafficking practices. Other issues concern domestic policies of the target state. Since we are interested in how far sanctions can achieve the goal of democratization, we focus on sanctions with domestic policy issues: i.e. human rights violations, electoral fraud, violations of the constitutional order, and enhancing leadership change, similar to the approach by von Soest and Wahman (2015a). Therefore, we drop all sanction cases that do not involve at least one of these domestic policy issues. Moreover, we focus on the EU and the US, as these are the two senders that most actively promote democratization.

Independent of whether the issue refers to internal or external policies, the sanction types range from complete economic embargoes and trade restrictions to aid cuts and targeted sanctions. While it could well be that sanction types matter, we include all types of sanctions. On the one hand, we regard sanctions as external top-down pressure on target governments, which can be increased by sending aid to civil society to create bottom-up pressure or decreased by sending it to the target government. For the theoretical argument, a further disaggregation of the different types of sanctions is thus not necessary. Moreover, when we look at sanctions with the goal of promoting democracy, broad country programs are very rare. Considering both EU and US sanctions together, there are 97 sanction cases that are ongoing over 574 country-years. Out of these cases, only ten include economic embargoes or trade measures. All other sanctions are targeted sanctions, arms embargoes, or aid sanctions. The latter sanction type is somewhat problematic for our analysis as it implies that sanctions and aid are simultaneously determined. We believe that our proposed mechanism that drives the interaction effects is not affected if the effect of an aid sanction is directly visible in the respective aid flow. In cases where the EU and/or the US impose sanctions by restricting foreign aid while there are still high levels of aid flows channeled through the public sector (for example when aid restrictions only apply for very specific areas such as military assistance), we expect that the sanctions do not have a strong effect. On the other hand, when sanctions are in place and aid flows channeled through the public sector are mostly cut off, we expect that the measures are more likely to have an effect. It makes a difference whether aid flows are determined by sanctions or whether their amount cannot be 
explained by such a coercive policy. For the underlying mechanism it is thus necessary that the sender decides to impose a sanction, but the sanction type should not have an impact on the interaction effect. However, to ensure the robustness of our results, we estimate our models for both democratic sanctions as well as non-aid democratic sanctions.

Second, we consider the amount of aid. Our theory is based on the distinction between aid to governments and aid flows to civil society. For our empirical evaluation, we employ the OECD (2017) CRS Aid Activity database, which provides information on the channels of aid delivery. Thus, we have two different aid types as explanatory variables: we estimate the effects for and differentiate between public sector aid per capita (aid channeled through the public sector divided by the population) and civil society aid per capita (aid channeled through NGOs and the civil society divided by the population). ${ }^{4}$ We employ the lagged sum of aid disbursements per capita in dollars from all EU member states and institutions as well as the United States. Moreover, we take the $\log$ of these values because of their right-skewed distribution. The distributions of these logged aid data are depicted in Figure 1-4.

As control variables, we include the total net official aid disbursements to the respective country (OECD 2017) because the effects of the amount of aid by the two senders might change when third states also cut aid flows or compensate the losses by giving additional aid (Early and Jadoon 2016). To capture these spillover effects, we include the lagged and logged total amount of aid in dollars per capita. Moreover, we control for coups (dataset by Powell and Thyne 2011), which jointly explain changes in the democracy score and sanctions in the respective country-year. Additionally, we include the occurrence of armed conflicts and one-sided violence in the previous year (Allansson, Melander, and Themnér 2017; Pettersson and Eck 2018) because they are both likely to impact the imposition of sanctions and disbursement of aid (Donno and Neureiter 2018). Besides these political control variables, we include the population size, the annual GDP per capita, and GDP growth (The World Bank 2017 and 2018) to control for size, economic power, as well as economic development. These three variables are also logged and lagged by one year. We provide summary statistics and a correlation matrix in the Appendix.

\section{Empirical Analysis}

Before we analyze the effect of democratic sanctions and the two different types of aid flows on democratization, we provide some descriptive statistics of the two key independent variables. With regard to sanctions, the EU is involved in 81 imposed sanction cases of which 59 cases in 47 countries are related to domestic

${ }^{4}$ Data for the population size were obtained from The World Bank (2017). 

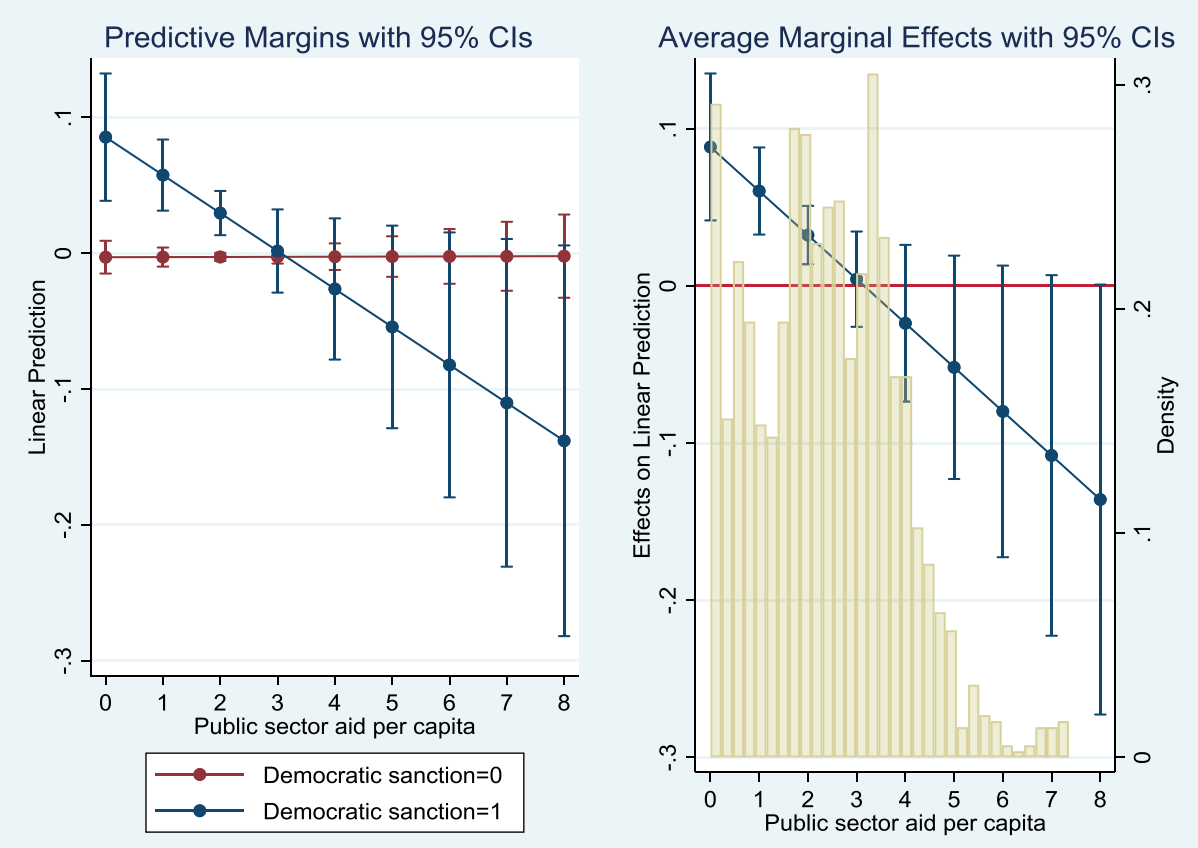

Figure 1. Effect of democratic sanctions depending on level of public sector aid (Table 1, model 4).

policy issues. The US is involved in 87 democracy-related sanction cases in 60 countries (in addition to 95 cases that are not related to domestic policy issues). Taken together, out of 199 countries, 63 states face democratic sanctions by at least one of the two senders during our period of observation. The regional focus does not differ much between the EU and the US: more than half of the targets are African countries, followed by countries in Asia and Eastern Europe. Countries targeted by both the EU and the US have a significantly lower mean $\mathrm{V}$-Dem democracy score than the average score of all countries (simple t-tests have a $p$-value of virtually zero). When we regard targeted countries, 26 have received more civil society aid than the average amount in at least one year (Burma, the Democratic Republic of the Congo, Somalia, Sudan, and Zimbabwe in more than half of the period covered). Conversely, 14 countries have received more than the average amount of public sector aid in at least one year (most often China, the Democratic Republic of the Congo, and Egypt).

The correlation of the amount of civil society and public sector aid per capita is positive but negligible (the Person's correlation coefficient is 0.12). Regarding the correlation between the amount of civil society and public sector aid per capita when democratic sanctions are imposed, the coefficient is slightly higher, but still only shows a moderate correlation $(0.25)$. The same holds for non-aid democratic sanctions, for which this correlation is 0.21 . Finally, we consider the association between sanctions and aid. We therefore 

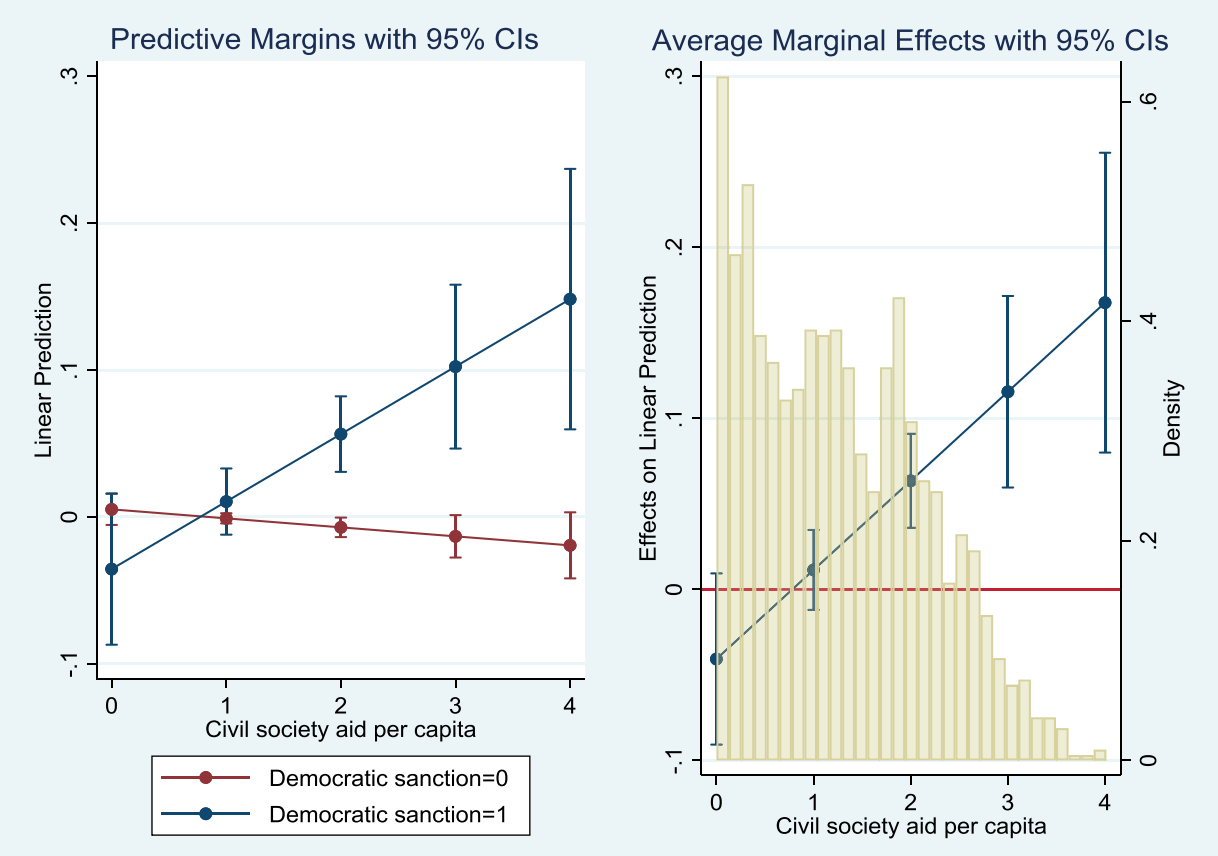

Figure 2. Effect of democratic sanctions depending on level of civil society aid (Table 1, model 4).

run two-sample t-tests for both civil society and public sector aid per capita by country-years with and without democratic sanctions. On the one hand, country-years with democratic sanctions are associated with significantly less public sector aid ( $p$-value of virtually zero), irrespective of considering all democratic sanctions or only non-aid democratic sanctions. On the other hand, there is no statistical significant difference between any of these groups in the amount of civil society aid per capita, which gives us confidence that the empirical analysis of the core of our theory is not biased.

\section{Analysis of the Effect of Democratic Sanctions and Aid Flows}

Our hypotheses refer to the combination of aid and sanctions. For analyzing the effect of democratic sanctions and the two different types of aid flows (public sector vs. civil society aid per capita) on the level of democratization, we thus estimate the interaction effects of sanctions and our set of aid disbursements on changes in the V-Dem Electoral Democracy Score. Table 1 shows the effect of EU and US democratic sanctions, aid flows differentiated by the channel of delivery, and the interaction effects between sanctions and both types of aid. In Table 2, we provide the same models for non-aid democratic sanctions. In both tables, the first column only includes the dummy for democracy-related sanctions, the two different aid flows, and the respective interaction effects. In 


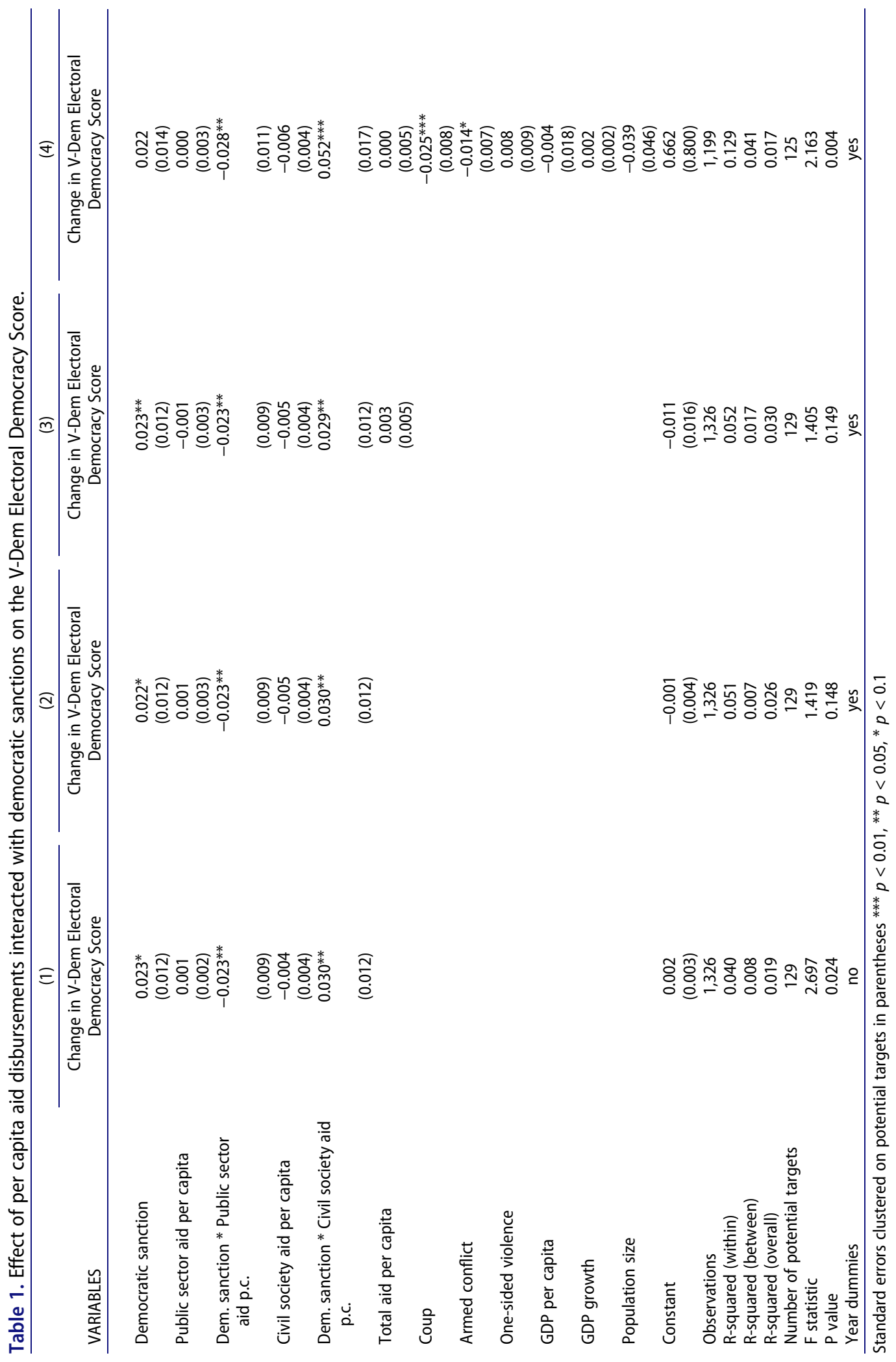




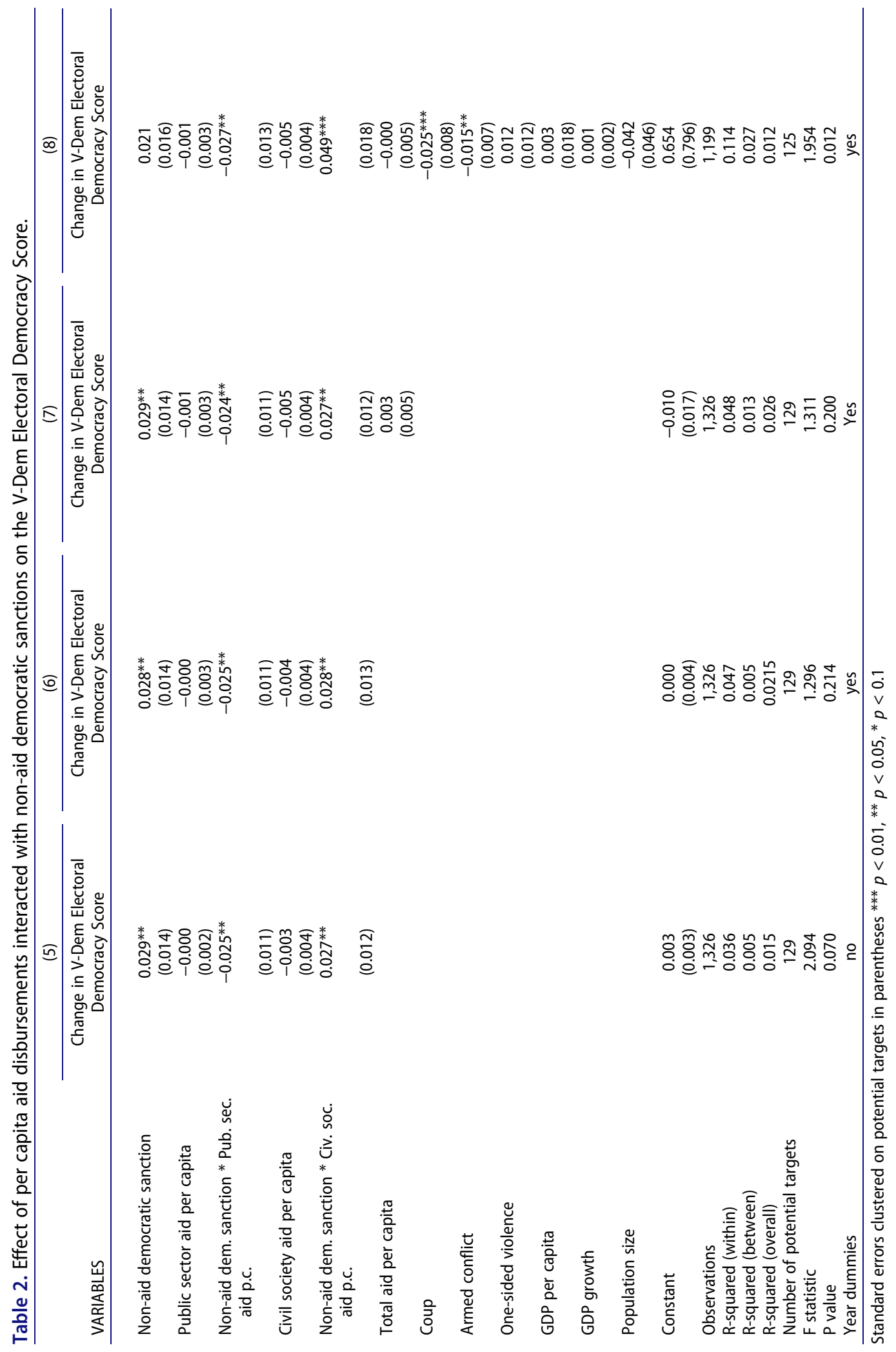


the second model, we account for temporal dynamics and include year dummies, thus estimating two-way fixed effects. Moreover, we also control for the total amount of aid in the previous year in the third column. Finally, in column 4, we further include all other control variables.

Since we interact democratic sanctions with both types of aid, the baseline coefficient for sanctions does not have a meaningful interpretation. However, we can say that independent of the channel of delivery, there is no effect of any type of aid on the V-Dem democracy score when there are no sanctions in place. For both democratic sanctions and non-aid democratic sanctions, we can see that when these measures are employed, aid channeled through the public sector has a negative effect on changes in the V-Dem democracy score. Contrarily the coefficient of the interaction between sanctions and aid channeled through NGOs and the civil society is positive. The interactions are all at least significant at the level of 5\%. The occurrence of military coups and armed conflicts are the only control variables that are significant in both panels and have a negative effect on changes in the V-Dem democracy score, as expected. The control variables for the size of the target, its economic power, as well as its economic development do not have an effect.

Figure 1 to 4 display these interaction effects graphically. The left-hand graphs show the predictive margins: the effect of the respective level of aid (keeping all other variables as they are) if there were no sanctions in any country-year (red line) and a sanction in all country-years (blue line). The right-hand graphs depict the average marginal effect of a democracy-related sanction for each level of aid, which is the difference between the predictive margins. Additionally, the right-hand graphs show whether the average marginal effects are significant and include the histogram of the respective type of aid. Since the effect of any type of aid is insignificant and virtually zero in all models, the predictive margins and average marginal effects are visually indistinguishable in some cases.

The results provide evidence for our two hypotheses: first, the positive effect of sanctions on the democracy score diminishes, the higher the amount of aid channeled through the public sector (Figure 1 for democratic sanctions, Figure 3 for non-aid democratic sanctions). Therefore, sanctions have a less positive impact on the level of democratization in target countries when they are combined with aid channeled through the public sector. Second, there needs to be a certain level of civil society aid for sanctions to have a positive average marginal effect on the level of democratization. Therefore, these findings support our hypothesis that democracy-related sanctions lead to a higher level of democracy in target countries if they are combined with aid bypassing the recipient government.

We are aware that there are possible endogeneity issues in the relationship between sanctions, aid, and changes in democracy scores. However, we do not 

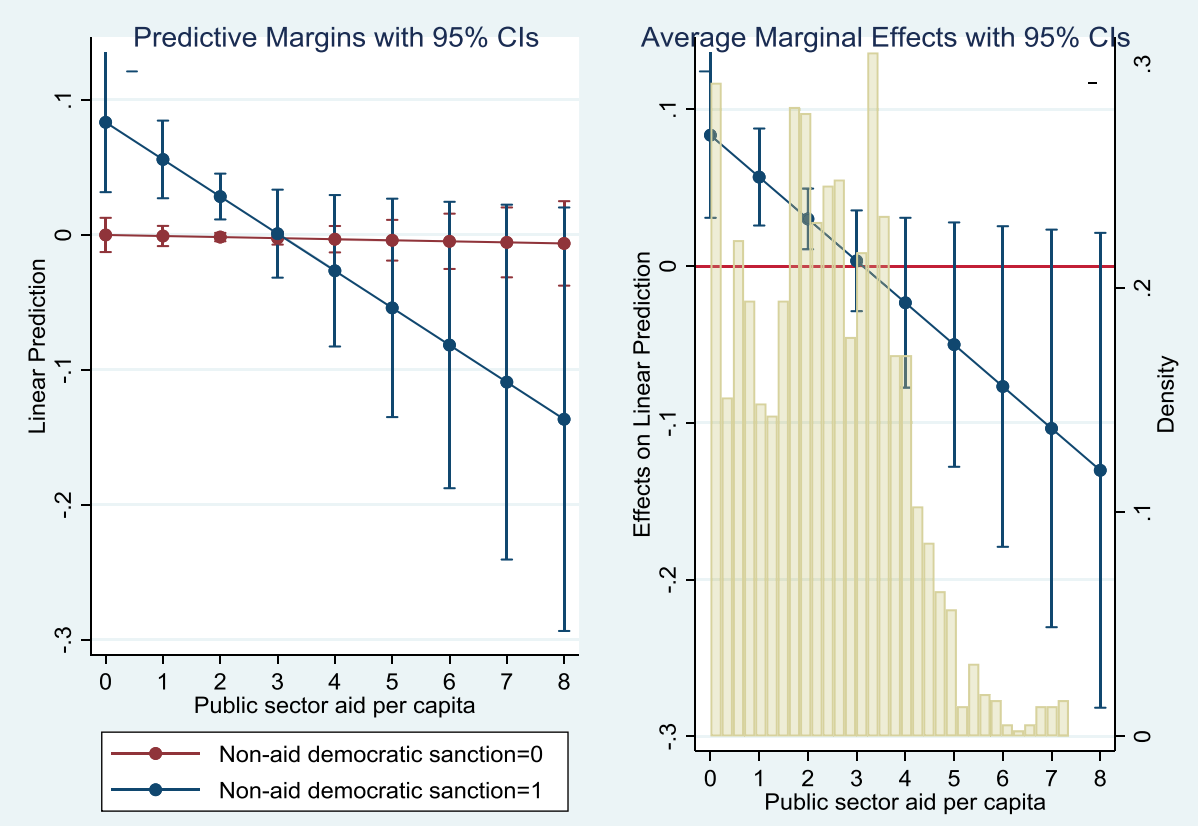

Figure 3. Effect of non-aid democratic sanctions depending on level of public sector aid (Table 2, model 8).

think that endogeneity threatens the validity of our findings. First, we lag our independent variables by one year to account for the order of events (except for coups that are expected to have an immediate effect). Since changes in the level of democracy can also lead to both an imposition of sanctions and changes in the amount of aid, we estimate the effects of preceding sanctions and aid flows on changes in democracy scores, thus ensuring that our results are not driven by reversed causality. Second, we use fixed-effects panel models to control for unobserved time-invariant unit-specific confounders, which can simultaneously have an impact on the imposition of sanctions or disbursement of aid and changes in democracy scores. Third, we control for coups (as well as conflicts and one-sided violence), which are the most common confounders that cause changes in democracy scores and serve as "trigger events" (von Soest and Wahman 2015b) for the imposition of sanctions. In fact, the coefficient for coups is negative and significant at the $1 \%$ level in all specifications.

Regarding the potential for endogeneity caused by omitted variables from a theoretical point of view: if there is some additional omitted factor that leads to both the imposition of sanctions and a negative change in the democracy score (i.e. a positive correlation between the omitted and the independent variable; and a negative effect of the omitted variable on the dependent variable), there is a negative bias. Since we predict and find a positive effect 

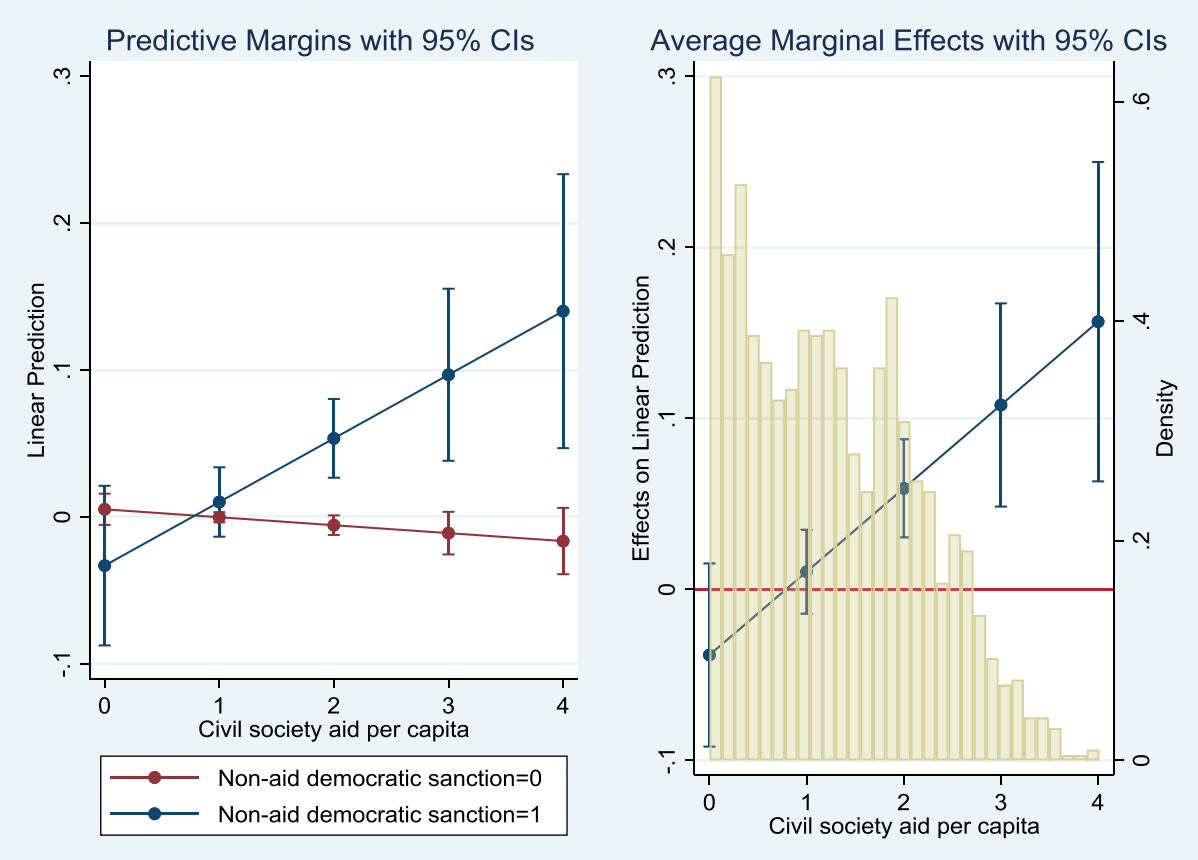

Figure 4. Effect of non-aid democratic sanctions depending on level of civil society aid (Table 2, model 8).

of sanctions, this endogeneity concern makes our results more conservative because the real effect of sanctions would even be stronger in this case. Similar considerations hold for the interaction between sanctions and civil society aid. Our results would only be biased if there was an omitted factor that has a positive (negative) effect on the democracy score while being positively (negatively) correlated with the imposition of sanctions. It is very hard to imagine an event that makes a country more democratic and which is associated with a greater likelihood for the imposition of sanctions.

In sum, we find that civil society aid is another important political variable that should be included in analyses of the effects of sanctions because both tools complement each other: democratic sanctions impose pressure on the government that is top-down, whereas non-governmental aid can induce pressure to democratize in target countries that is bottom-up. Our findings further imply that aid should not go to the government when sanctions are in place. The empirical results show that sending high amounts of aid to the public sector in a sanctioned country can undermine the effectiveness of democratic sanctions. We thus claim that once sanctions are imposed, it is better not to withdraw aid but rather shift aid to civil society because nongovernmental aid together with sanctions facilitates democratization. A sanctioned country is more likely to democratize when it receives aid that 
goes to civil society. These results are robust alternative measures for both our dependent and key independent variables as well as separate tests for both donors/senders.

Even though we are not concerned that our results are biased because of potential endogeneity, we conduct several robustness checks.

\section{Robustness Check}

To ensure the robustness of our results, first, we use alternative measures of aid instead of gross disbursements per capita in dollars. Since the selection of a certain scaling of aid might affect the results, we re-run the all models for three additional measures of aid: the absolute levels of the respective aid flows, aid per GDP per capita, and aid per GDP. Tables A3 to A5 in the online appendix display the results. The interaction effects between sanctions and public sector as well as civil society aid point into the expected direction for all three measures of aid. For the levels of aid and aid per GDP per capita, the coefficients are all at least significant at the $5 \%$ level. When we employ aid per GDP, the interaction effect between sanctions and public sector aid becomes insignificant. However, at the same time, we obtain the largest and most significant results for the interaction between sanctions and civil society aid, which is the core of our theoretical framework: generating top-down and bottom-up pressure on target governments.

Second, we re-run the previous models with an alternative dependent variable. So far, we considered changes in the V-Dem Electoral Democracy Score since we focus on democracy-related sanctions. However, since we expect aid channeled explicitly through civil society to increase the effect of democratic sanctions, we check whether our results hold when we consider changes in the V-Dem Civil Society Index (Coppedge et al. 2017). Tables A6 and A7 in the online appendix show the effects of both democratic sanctions and non-aid democratic sanctions on changes in this index, which is based on indicators for entry and exit, repression, and the participatory environment of civil society organizations (Bernhard et al. 2017). The interactions all keep pointing to the expected direction. However, while the interactions between (non-aid) democratic sanctions and public sector aid are also still significant, the coefficients for the interaction between sanctions and civil society aid lose their significance once we include all control variables in the final specification. Since the scope of the V-Dem Electoral Democracy Score is much broader than the scope of the Civil Society Index and since democracy-related sanctions do not explicitly aim to expand civil society, it is not surprising that the results are weaker. However, even though the coefficients are not significant, there are still significant average marginal effects for certain levels of the respective aid flow that point to the expected direction. Nevertheless, it is noticeable that, in the absence of sanctions, the amount of civil society aid does also not have a significant and positive 
effect on changes in this index (the coefficients are even negative). In sum, we find that the general results and conclusions hold when we consider changes in the V-Dem Civil Society Index instead of the Electoral Democracy Score. The effects are just not as strong because the Civil Society Index is less broad and not so explicitly targeted by democratic sanctions.

Finally, the European Union and the United States are very distinct actors, both in the way in which they impose sanctions and provide aid as well as in the way in which they promote democracy. To ensure that our results are not driven by a specific actor, we regard the individual effects of both donors/ senders separately. In Tables A8 and A9 in the online appendix, we thus run the models for EU and US sanctions and aid only. To capture the economic interlinkages with the respective actor, we also take into account trade flows in these models. Therefore, we include the sum of exports and imports from the EU (Eurostat 2017) and the US (Barbieri and Keshk 2016) in euros/dollars, respectively. The previous results hold, even though the negative interaction between democratic sanctions and public sector aid is only significant for US sanctions. Again, the occurrence of coups and armed conflicts are the only control variables that are significant in both panels and have a negative effect on changes in the V-Dem democracy score. By showing that our hypothesized interaction effects hold for both of these actors, in particular for the interaction between sanctions and civil society aid, we intend to strengthen the empirical evidence for our theory.

\section{Conclusion}

In this article, we have examined the impact of two democracy promotion tools: democratic sanctions and foreign aid. We theorized that there is a conditional relationship between democratic sanctions and two different types of aid provided to target states: aid to the civil society and aid to the public sector. Specifically, we expected to find that during democratic sanctions, higher levels of aid given to target governments are associated with reductions in their democracy levels. In contrast, higher levels of aid sent directly to civil society in target states will be associated with increases in target countries' democracy levels. By examining contemporary sanctions episodes involving the US and EU as senders and donors, we find robust support for our hypotheses.

Building on the vast literature on aid and democracy, this study has explored how the use of external interventions, i.e. sanctions and aid, can affect democratization in target countries, which we believe is an interesting and novel contribution. Specifically, we show that sanctions as democracy promotors work better than using them alone if combined with higher volumes of aid that bypass the government. However, we are aware that while our evidence is encouraging, yet much work remains. Although this is 
the first study combining in a systemic way bottom-up and top-down foreign policy tools to promote democracy, the limitation of our research is that we deal with observational data. We would like to encourage further investigation into an interesting and important question about the effectiveness of different democracy promotion tools using mixed methods. Future research should also study the interaction between these tools in authoritarian versus democratizing countries, especially. Given the anti-democratic measures taken by certain governments of EU democratic member states, and the EU's efforts to impose sanctions on these states, as well as illiberal measures also taken by established democracies, we are convinced that scholars will find this topic to be timely and important in years to come.

We hope that the findings reported in this article highlight avenues for future research on positive and negative incentives. Moreover, these findings also send an additional message to policymakers: when they anticipate imposing democratic sanctions on an oppressive government, they should have already cut aid to this government because the impact of sanctions is weaker when previous aid flows have already strengthened the governmental elites. Instead, policymakers should maintain connections with and strengthen civil society in the potential target country because incentive-oriented strategies toward civil society can prevent its isolation and empower it when sanctions are employed. Understanding how donors respond and should respond to the imposition of sanctions can help to make both tools of democracy promotion more effective.

\section{Acknowledgments}

The paper is a part of the joint research project EUSANCT conducted between Adam Mickiewicz University, Poznan, Poland and the University of Konstanz, Germany under the funding scheme of DFG/NCN Beethoven (UMO-2014/15/G/HS5/04845, DFG code: 749/15). An earlier version of the article was presented at the 113th APSA Annual Meeting and Exhibition, San Francisco, USA, 31 August- 3 September, 2017, and then was published as a V-Dem working paper.

\section{Funding}

This work was supported by the Deutsche Forschungsgemeinschaft (DFG) [749/15] and NarodoweCentrum Nauki [UMO-2014/15/G/HS5/04845] under the funding scheme Beethoven.

\section{References}

Abed, G.T., and S. Gupta, eds. 2002. Governance, Corruption, and Economic Performance. Washington, DC: International Monetary Fund.

Allansson, Marie, E. Melander, and L. Themnér. 2017. “Organized Violence, 1989-2016.” Journal of Peace Research 54 (4):574-87. doi:10.1177/0022343317718773 
Allen, Susan H. 2008. "The Domestic Political Costs of Economic Sanctions." Journal of Conflict Resolution 52 (6):916-44. doi:10.1177/0022002708325044

Baldwin, D.A. 1971. "The Power of Positive Sanctions." World Politics 24 (1):19-38. doi:10.2307/2009705

Baldwin, D.A. 1980. "Interdependence and Power: A Conceptual Analysis." International Organization 34 (4):471-506. doi:10.1017/S0020818300018828

Baldwin, D.A. 1985. Economic Statecraft. Princeton: Princeton University Press.

Barbieri, Katherine, and Omar M. G. Keshk. 2016. "Correlates of War Project Trade Data Set Codebook, Version 4.0.” Accessed 20 August 2017. http://correlatesofwar.org.

Bermeo, Sarah B. 2011. "Foreign Aid and Regime Change: A Role for Donor Intent.” World Development 39 (11):2021-31. doi:10.1016/j.worlddev.2011.07.019

Bernhard, Michael, D-J. Jung, E. Tzelgov, M. Coppedge, and S. I. Lindberg. 2017. "Making Embedded Knowledge Transparent: How the V-Dem Dataset Opens New Vistas in Civil Society Research." Perspectives on Politics 15 (2):342-360. doi:10.1017/S1537592717000056

Boone, Peter. 1995. Politics and the Effectiveness of Foreign Aid. London: Center for Economic Performance.

Bräutigam, Deborah A., and Stephen Knack. 2004. "Foreign Aid, Institutions, and Governance in Sub-Saharan Africa.” Economic Development and Cultural Change 52 (2):255-85. doi: $10.1086 / 380592$

Bueno de Mesquita, Bruce Bueno de Mesquita, Alastair Smith, Randolph M. Siverson, and James D. Morrow. 2003. The Logic of Political Survival. Cambridge: MIT Press.

Bueno de Mesquita, Bruce, and Alastair Smith. 2009. "Political Survival and Endogenous Institutional Change." Comparative Political Studies 42 (2):167-97. doi:10.1177/ 0010414008323330

Carneiro, Christiane L., and Laerte Apolinário. 2016. "Targeted versus Conventional Economic Sanctions: What Is at Stake for Human Rights?” International Interactions 42 (4):565-89. doi:10.1080/03050629.2015.1036989

Carothers, Thomas. 1999. Aiding Democracy Abroad: The Learning Curve. Washington, DC: Carnegie Endowment for International Peace.

Carothers, Thomas, and Saska Brechenmacher. 2014. Closing Space: Democracy and Human Rights Support under Fire. Washington, DC: Carnegie Endowment for International Peace.

Chenoweth, Erica, and Maria J. Stephan. 2011. Why Civil Resistance Works: The Strategic Logic of Nonviolent Conflict. New York: Columbia University Press.

Coppedge, Michael, John Gerring, Staffan I. Lindberg, Svend-Erik Skaaning, Jan Teorell, David Altman, and M. Michael Bernhard, et al. 2017. "V-Dem [Country-year/country-date] Dataset V7. In: Varieties of Democracy (V-dem) Project." Accessed 20 August 2017. https://www.v-dem.net/en/data/data-version-7/. (August 20, 2017).

Crawford, Gordon. 2001. Foreign Aid and Political Reform: A Comparative Analysis of Democracy Assistance and Political Conditionality. International political economy series. Houndmills, Basingstoke: Palgrave.

Dahl, Robert. 1971. Polyarchy. London: Yale University Press.

Dietrich, Simone. 2013. "Bypass or Engage? Explaining Donor Delivery Tactics in Foreign Aid Allocation.” International Studies Quarterly 57 (4):698-712. doi:10.1111/isqu.12041

Djankov, Simeon, Jose G. Montalvo, and Marta Reynal-Querol. 2008. "The Curse of Aid." Journal of Economic Growth 13 (3):169-94. doi:10.1007/s10887-008-9032-8

Donno, Daniela, and Michael Neureiter. 2018. "Can Human Rights Conditionality Reduce Repression? Examining the European Union's Economic Agreements.” The Review of International Organizations 13 (3):335-57. doi:10.1007/s11558-017-9283-2 
Dunning, Thad. 2004. "Conditioning the Effects of Aid: Cold War Politics, Donor Credibility, and Democracy in Africa." International Organization 58 (2):409-23. doi:10.1017/ S0020818304582073

Dursen, Peksen, and A. Cooper Drury. 2009. "Economic Sanctions and Political Repression: Assessing the Impact of Coercive Diplomacy on Political Freedoms." The Human Rights Revolution 10 (3):393-411. doi: 10.1007/s12142-009-0126-2

Early, Bryan R., and Amira Jadoon. 2016. "Do Sanctions Always Stigmatize? The Effects of Economic Sanctions on Foreign Aid.” International Interactions 42 (2):217-43. doi:10.1080/ 03050629.2016.1093477

Eurostat. 2017. "EU Trade since 1988 by SITC: [Data File].” Accessed 20 August 2017. http://ec. europa.eu/eurostat/data/database/

Finkel, Steven E., A. Pérez-Liñán, and M. A. Seligson. 2007. “The Effects of U.S. Foreign Assistance on Democracy Building, 1990-2003.” World Politics 59 (3):404-39. doi:10.1017/ S0043887100020876

Goldsmith, Arthur A. 2001. "Foreign Aid and Statehood in Africa." International Organization 55 (1):123-48. doi:10.1162/002081801551432

Grauvogel, Julia, Amanda A. Licht, and Christian von Soest. 2017. "Sanctions and Signals: How International Sanction Threats Trigger Domestic Protest in Targeted Regimes." International Studies Quarterly 61 (1):86-97.

Hufbauer, Gary C., Jeffrey J. Schott, Kimberly Ann Elliott, and Barbara Oegg. 2009. Economic Sanctions Reconsidered. 3rd. Washington, DC: Peterson Institute for International Economics.

Kalyvitis, Sarantis, and Irene Vlachaki. 2009. "Democratic Aid and the Democratization of Recipients.” Contemporary Economic Policy 28 (2):188-218. doi:10.1111/j.14657287.2009.00154.x

Kalyvitis, Sarantis, and Irene Vlachaki. 2012. "When Does More Aid Imply Less Democracy? An Empirical Examination.” European Journal of Political Economy 28:132-46. doi: 10.1016/ j.ejpoleco.2011.06.010

Keck, Margaret E., and Kathryn Sikkink. 1998. Activists beyond Borders: Advocacy Networks in International Politics. Ithaca: Cornell University Press.

Kono, Yuichi D., and G.R. Montinola. 2009. "Does Foreign Aid Support Autocrats, Democrats, or Both?” The Journal of Politics 71 (2):704-18. doi:10.1017/S0022381609090550

Kosack, Stephen, and Jennifer Tobin. 2006. "Funding Self-sustaining Development: The Role of Aid, FDI and Government in Economic Success." International Organization 60:205-43. doi: $10.1017 /$ S0020818306060097

Krasner, Stephen D., and Jeremy M. Weinstein. 2014. "Improving Governance from the Outside In." Annual Review of Political Science 17:123-45. doi: 10.1146/annurev-polisci $-120611-231838$

Lektzian, David, and Mark Souva. 2007. "An Institutional Theory of Sanctions Onset and Success.” The Journal of Conflict Resolution 51 (6):848-71. doi:10.1177/0022002707306811

Licht, Amanda A. 2010. "Coming into Money: The Impact of Foreign Aid on Leader Survival." The Journal of Conflict Resolution 54 (1):58-87. doi:10.1177/0022002709351104

Lührmann, Anna, Kelly McMann, and Carolien van Ham. 2016. "Political Conditions for Effective Democracy Assistance.” Unpublished Working Paper.

Marinov, Nikolay. 2005. "Do Economic Sanctions Destabilize Country Leaders?" American Journal of Political Science 49 (3):564-76. doi:10.1111/j.1540-5907.2005.00142.x

Marinov, Nikolay, and Shmuel Nili. 2015. "Sanctions and Democracy." International Interactions 41 (4):765-78. doi:10.1080/03050629.2015.1036723

Morgan, T.C., N.A. Bapat, and V. Krustev. (2009). The threat and imposition of sanctions, 1971-2000. Conflict Management and Peace Science 26 (1):92-110. 
Morgan, T. Clifton, N. Bapat, and Y. Kobayashi. 2014. “Threat and Imposition of Economic Sanctions 1945-2005: Updating the TIES Dataset.” Conflict Management and Peace Science 31 (5):541-58. doi:10.1177/0738894213520379

OECD. 2017. "CRS Aid Activity Database: [Data File]." OECD Stat. Accessed 22 August 2017. https://stats.oecd.org/index.aspx?DataSetCode=CRS1

Peksen, Dursun, and A. Cooper Drury. 2010. "Coercive or Corrosive: The Negative Impact of Economic Sanctions on Democracy.” International Interactions 36 (3):240-64. doi:10.1080/ 03050629.2010.502436

Peksen, Dursun, and Byungwon Woo. 2018. "Economic Sanctions and the Politics of IMF Lending.” International Interactions 44 (4):681-708. doi:10.1080/03050629.2018.1429427

Pettersson, Therése, and Kristine Eck. 2018. “Organized Violence, 1989-2017.” Journal of Peace Research 55 (4):535-47. doi:10.1177/0022343318784101

Portela, Clara, and Christian von Soest. 2012. GIGA Sanctions Dataset Codebook: Version 18 June 2012. Hamburg: GIGA German Institute of Global and Area Studies.

Powell, Jonathan M., and Clayton L. Thyne. 2011. "Global Instances of Coups from 1950 to 2010: A New Dataset." Journal of Peace Research 48 (2):249-59. doi:10.1177/ 0022343310397436

Rajan, Raghuram, and Arvind Subramanian. 2007. “Does Aid Affect Governance?” American Economic Review 97 (2):322-27. doi:10.1257/aer.97.2.322

Sedelmeier, U. 2014. "Anchoring Democracy from above? The European Union and Democratic Backsliding in Hungary and Romania after Accession." JCMS: Journal of Common Market Studies 52 (1):105-121.

Stephan, Maria J., and Erica Chenoweth. 2008. "Why Civil Resistance Works: The Strategic Logic of Nonviolent Conflict." International Security 33 (1):7-44. doi:10.1162/ isec.2008.33.1.7

Teorell, Jan, Coppedge Michael Skaaning, Svend-Erik, and Lindberg Staffan. 2016. "Measuring Electoral Democracy with V-Dem Data: Introducing a New Polyarchy Index.” V-Dem Working Paper Series 25.

The World Bank. 2017. "World Development Indicators [Data File].” Accessed 27 June 2017. http://data.worldbank.org/.

The World Bank. 2018. "World Development Indicators, Net Official Development Assistance and Official Aid Received (Constant 2015 US\$).” World Bank Open Data. Accessed 13 August 2018. http://data.worldbank.org/.

von Soest, Christian, and Michael Wahman. 2015a. "Are Democratic Sanctions Really Counterproductive?" Democratization 22 (6):957-80. doi:10.1080/13510347.2014.888418

von Soest, Christian, and Michael Wahman. 2015b. "Not All Dictators are Equal: Coups, Fraudulent Elections, and the Selective Targeting of Democratic Sanction." Journal of Peace Research 52 (1):17-31. doi:10.1177/0022343314551081

Weber, Patrick M., and Gerald Schneider. 2020. "Post-Cold War Sanctioning by the EU, the UN, and the US: Introducing the EUSANCT Dataset.” Unpublished Working Paper. University of Konstanz.

Welzel, Christian, and Ronald Inglehart. 2008. "The Role of Ordinary People in Demcoratization." Journal of Democracy 19 (1):126-40. doi:10.1353/jod.2008.0009

Whitehead, Laurence. 1996. The International Dimensions of Democratization: Europe and the Americas. Oxford: Oxford University Press.

Youngs, Richard. 2010. The European Union and Democracy Promotion: A Critical Global Assessment. Baltimore: Johns Hopkins University Press. 